\title{
CDKAL1 Gene
}

National Cancer Institute

\section{Source}

National Cancer Institute. CDKAL1 Gene. NCI Thesaurus. Code C131362.

This gene plays a role in transfer RNA methylthiolation. 